\title{
THE ADVOCATE, THE TRUTH, AND JUDICIAL HACKLES: A REACTION TO JUDGE FRANKEL'S IDEA
}

\author{
H. RICHARD UVILLER $\dagger$
}

\section{INTRODUCTION}

It must be distressing to preside over the rape of Truth in the courtroom. At the altar of justice, before the Judge's very eyes, the atrocity is perpetrated in a casual, routine manner bespeaking long and regular usage. And the rapists are people who proclaim themselves honorable and devoted to the victim. Apart from the occasional nostalgic ex-litigator who relishes the spectacle, the judicial witness may be tempted, understandably enough, to take a more heroic role.

But if the judge breaks with customary passivity, vaulting the bench and riding to the rescue, his merciful mission often turns out to be a lame and embarrassing sortie. It's enough to raise a judicial hackle or two.

Judge Frankel's hackles are as stable as most, to my knowledge. Yet they are clearly ascending. Their rise invites us to revisit an old acquaintance: the adversary myth. Our beloved dialectic model of litigation offers much in the way of healthful mental exercise, he suggests, but the "Truth" that emerges may be more synthetic than real. For the collision of opponents is better designed to find an athletic victor than to search for Truth. Still, it seems to me that properly directed and purged of obvious abuses, the juxtaposition of two contrary perspectives, the impact of challenge and counter-proof, often discloses to a neutral intelligence the most likely structure of Truth. Thus, at least in those instances (which I may regard as more common than does Judge Frankel) where neither side knows certainly the actual contours of a past occurrence, I conclude that the adversarial encounter, for all its hazards, serves as one of the better methods of reconstruction.

Venturing into the causes of Judge Frankel's dissatisfaction and appraising his call for major surgery on the system, it may

† Professor of Law, Columbia University. B.A. 1951, Harvard University; LL.B. 1953, Yale University. Member, New York and District of Columbia Bars. 
be well from the start to keep separate systemic flaws and overlaid abuses. For the essence of Judge Frankel's argument is that the design of the adversary system itself is responsible for the dangerously recurrent violation of Truth, whereas it may be that the ills that trouble him are attributable to improper excesses of advocacy. And Judge Frankel, being as conservative as $I$ in such things, would probably reject radical surgery if lesser measures might relieve the condition.

Few would dispute Judge Frankel's theorem that Truth often suffers in the courtroom. He rightly reminds us that in those relatively few cases (civil or criminal) that go to trial, one side or the other seeks-wittingly or unwittingly-to defeat Truth. Indeed, it is likely that neither party is advancing the entire Truth as some Omniscient Recorder might know it. And it may well be that if both lawyers told each other or the court (with ideally matched generosity) all that they knew or suspected concerning the facts, the result might bear a somewhat closer resemblance to the past event in issue. Further, if our Judge could preside in the Southern District of Utopia where trial lawyers, including criminal defense counsel, act as diligent investigators for their opponents, even finer details of Truth might be supplied.

Insofar as Judge Frankel is disturbed by the penchant of terrestrial attorneys to argue contrary to, or independently of private belief, he has ample cause for discomfort. Few experienced and successful advocates do not count among their wellworn tools some devices to conceal at least a part of what they believe to be the factual truth. Many can recall instances in which they advanced in court factual propositions the strict accuracy of which they had cause to doubt, or sought to discount or discredit evidence they had reason to think was true. And I venture that, at least among defense counsel in criminal cases, the concession causes little regret or chagrin. The adversary system, in which trial lawyers are trained and participate, serenely countenances such techniques-short of subornation of perjury. The rewards of victory are rarely marred by the victor's misgivings over whether the verdict actually spoke the truth. And for those lawyers who might pause over some tactical choice designed to dim the full glare of truth, several available maxims of self-justification offer to sooth his scruples.

I cannot grant a priori, however, that the prevalent ethic supporting such license inheres in the adversary system. While 
free sharing of the product of partisan investigation may not comport with the adversarial model-at least as applied to criminal defendants, the concealment or distortion of known facts is no necessary corrollary of contention.

This is not to say that I, any more than Judge Frankel, believe that the remedy for such impropriety may be found in more intensive law school instruction on the subject of ethics. The notion that virtue and upright deportment at the bar can be taught to law students like trusts or the Uniform Commercial Code seems to me unrealistic and self-deluding. Nor (with due deference to the dignity of its proponents) can the faults of advocates in this regard be assigned to lack of skill. The Judge is surely correct when he points out that the conventional skills of adversaries include the techniques of truth-bending.

I cannot be so certain that Judge Frankel is right, however, when he rejects also the remedial role of the judge presiding. ${ }^{1}$ He acknowledges that other respected judges have derived a contrary conclusion from their experiences. And at least some judges who try less complex, more hastily prepared cases report that their interventions usually have a healthy effect on the emergence of Truth from the adversary fray. Yet my own inclination is with Judge Frankel's to the effect that a trial judge is poorly positioned and informed to perceive or rescue Truth in the midst of a trial. And his errors are costly, since his view of Truth must align his formidable presence with one of the partisans. To many of us, imbued with the American model, such a fall from neutrality is a primal sin.

Thus, for what it is worth, I endorse Judge Frankel's assessment of (1) the frequency of adversarial liberties taken with Truth in the American trial process; (2) the strange shape of an ethic which tolerates if it does not encourage the advocate's

'I think Judge Frankel speaks throughout (as I do) of the judge's role in a jury trial. To me, a bench trial is an altogether different event. To allow counsel to manage the production of proof before a judicial factfinder as though he were a naive, lay, mute jury may be a blind and wasteful devotion to an inappropriate trial format. Perhaps, after a full and proper introduction to the issues, and with continuing guidance, counsel should allow the case to be developed by the judge. In bench trials, then, a major role in the interrogation of witnesses should be taken by the judge who should explore the issues of importance to him to the extent he deems necessary for his own illumination. Choosing to waive a jury, the parties might be deemed to have endowed the court with greater initiative and freedom in the factual inquiry, and neither the inquisitorial spectre nor the prospect of a judicial stumble or two should be allowed to firighten us from an otherwise sensible procedure. But all this is outside the scope of our present concern, I believe, and might be left to somé future piece. 
disregard for the facts as he knows them; and (3) the impotence of the commonly proposed methods of prevention and counteraction. To these endorsements, however, I must append a few misgivings.

\section{The Advocates}

First, and by way of a preliminary quibble, I dissent from the Judge's inclusion of public prosecutors among his licensed Truth-defilers. To be sure, prosecutors sometimes conceal all or a portion of the evidence they have unearthed about a case; sometimes they sit quietly by as a helpful witness distorts the facts; in short the prosecutor's conduct may mirror defense counsel's partisan assault on Truth. But in every such deplorable instance, the prosecutor-unlike defense counsel-violates his ethical duty and perhaps the law as well. ${ }^{2}$ The Code of Professional Responsibility enjoins defense counsel to be faithful, resourceful and relentless in the service of his client's interest. No such injunction directs the prosecutor; he has no client, no interest save the interest of justice. ${ }^{3}$ And the interest of justice is not a partisan cause. Jencks, ${ }^{4}$ Brady, ${ }^{5}$ Napue, ${ }^{6}$ and a thousand other cases and codes urge the prosecutor to divulge harmful facts fully and to foster Truth. Moreover, I believe the conscience of most prosecutors to be bent as the law would bend it: to exert all precautions against the calamity of an innocent person convicted of a crime. This ethic, of course, does not address the prosecutor's failure to prosecute someone he believes to be truly guilty (if that is part of the substance of Judge Frankel's accusation), but I submit that such inaction is of a different order of offense to Truth. Without elaborate (and perhaps questionable) argument supporting that submission, I would simply aver that Judge Frankel's final reformulation of DR $7-102,7$ the embodiment of his point, has done no more than articulate and decree for the bar generally the ethical imperative currently controlling prosecutorial conduct in litigation.

${ }^{2}$ See Uviller, The Virtuous Prosecutor in Quest of an Ethical Standard, $71 \mathrm{Mrch}$. L. Rev. 1145 (1973). See also ABA Code of Professional Responsibility DR 7-103, EC 7-13.

3 ABA Code of Professional Responsibility EC 7-13.

${ }^{4}$ Jencks v. United States, 353 U.S. 657 (1957).

5 Brady v. Maryland, 373 U.S. 83 (1963).

${ }^{6}$ Napue v. United States, 360 U.S. 264 (1959).

7 ABA Code of Professional Responsibility DR 7-102. 
I should also add, in a personal vein, that, having performed most of my courtroom services in the role of prosecutor, obedient (I hope) to the precepts advanced by Judge Frankel, I am tempted to declare that I see nothing onerous in calling upon the rest of the bar to live by the strictures familiar to me. "If I can do it, they can do it," and "we'd all be better off if everyone were as virtuous as I" are both notions which fall readily to hand despite the dictates of due modesty. Yet, I can not let arrogance win the day by default. And I am constrained by ordinary sense to acknowledge that the prosecutor's finest blossoms may not thrive in the garden of the defense. I must get on with my deeper misgivings concerning the judge's appealing thesis.

For me, the main difficulty in assimilating Judge Frankel's lesson has been my uncertainty whether I was hearing a simple and rather tired lament on the shortcomings of adversarial truth-seeking or a refreshed and envigorated proposal for basic restructure of our mode of determining facts in litigation. My perplexity stems, I think, from Judge Frankel's choice not to explore the refinements and implications of his thesis. For, while recognizing some of them, the Judge has deferred treatment, labelling his efforts tentative, preliminary, and provocative only. I do not disparage the privilege of broad statement nor denigrate the value of a thoughtful report of experience from the judicial vantage. Indeed I admire the courage of the Judge to raise for discussion a notion so familiar as commonly to pass without serious notice. I say only that in his humility, the Judge has assigned to others the analytic task which will validate or destroy his suggestion.

Take, for example, the implications of his revision upon the traditional American relationship between counsel and client. The canons Judge Frankel criticizes reflect our esteem for fidelity between the lay and professional partners. In his obedience to his client's cause, in his service of the client's interest, the lawyer is expected to eschew only the grossest personal or professional dishonor. The lawyer is employed not as a detached and judgmental intelligence, but as a weapon. In litigation, at least, the lawyer's performance and advice is to serve a partisan interest. Could we live with a system in which the lawyer's faith was divided? In which he felt a stronger obligation to enhance a result which conflicts with the interest of the party engaging his talent? 
An early casualty of the proposed new purpose of the assistance of counsel for the defense (to borrow the language of the Sixth Amendment) would be the confidentiality assured by the lawyer-client privilege. ${ }^{8}$ For a lawyer, obedient to the Frankel Tenet, could not promise his client that his preliminary disclosures might not injure his cause. The lawyer, preparing for trial, would be bound to exert efforts to learn the true facts and however that Truth may cut, to lay it fully before the court. And, ideally, defendants would know that they could enlist no lawyer to shade or obscure the Truth. A public appreciation of this new ethic would doubtless improve the sagging repute of the bar. And such detached professional conduct might well improve the truth-detecting capability of the trial mechanism. But (at least according to the general assumption) the candor of a defendant to his lawyer would appreciably shrivel.

How grievous is this presumed consequence? I, for one, find it difficult to assess. In counselling, it may be that the lawyer requires and obtains complete and trusting disclosure from his client. Many lawyers report that, in the commercial context at least, it is comparatively easy to steer a basically honest client away from evil or over-reaching purposes. Concealment and distrust could only hamper these worthy professional purposes. Yet even discussions for present counselling must contemplate litigation however remotely, and to that extent suffer from the consequence of the Frankel impairment of secure confidence.

For defense counsel in criminal cases, I suspect, diminution of the privilege would have substantially less impact. Although some defense attorneys stoutly insist that they probe the client's guilt and fashion the defense accordingly, I don't believe this mode of defense is the rule. Generally, I think, "Truth" simply is not an operative factor to a defense lawyer. Few lawyers believe their clients tell them the unvarnished truth about the case (privilege or no), and few lawyers insist that they do so. The version of the facts requested and obtained is the defendant's "story." It may or may not be true, but the prime concerns of the lawyer are only two: first, is the story convincing, and second, does it meet adequately well the more damaging aspects of the prosecution account (so far as it may be learned in ad-

${ }^{8}$ Unless, perhaps, Judge Frankel means to blunt the principal thrust of his argument by the exception provided in the revised canon he sets forth at the end of his piece. 
vance). Of course, the lawyer should do nothing to "improve" the story in either respect. But he would be remiss if he failed to strike it here and there (in the supposed privacy of a client conference) to test its ring of truth on the anvil of prospective cross-examination. And it is not extraordinary for the story to change somewhat in the process, usually acquiring a clearer and more persuasive tone. However, we should not confuse the lawyer's activity here with Truth seeking-although the revised "story" may be truer than the first in the sense of a more complete and accurate rendition of recalled facts. Nor should the Judge, or others, suppose that the lawyer is here administering the first painful twist on Truth-although he may be indirectly counselling truth-concealing wrinkles to a client alert for hints toward the development of a winning defense. In fairness, I submit, this essential and thoroughly professional preparatory conference can only be taken as having nothing whatever to do with Truth. Aiming neither to enhance nor subvert it, and having little or no reliable basis for judging his impact on Truth, counsel seeks only to explore the strengths and weaknesses of the story he must advance in court. The openness and fluidity of this preliminary conference may be impaired by weakening the protection of the attorney-client privilege. But, if my informants in the defense bar are to be credited, there is little to lose in the way of Truth.

More disturbing than the possible harm to candor is the hint in Judge Frankel's proposal that defense counsel, preparing his case for trial, is somehow obliged to further the prosecution's investigation at the same time. Not only would Judge Frankel make available to the court what the lawyer knows of the issue, but what diligent effort might discover. Does this not suggest that the defendant has acquired and paid for an agent for his prosecution as well as the assistance of counsel for his defense? The proponent of this double-agency pauses only momentarily to wonder about the appropriate fee for uncertain fealty and diminished fervor. He leaves to others the description and evaluation of the fundamental alteration in the character of legal representation which his new ideology imports. For myself, though rectitude at the bar has a pleasanter odor than the morality of the mercenary warrior, I confess to a shiver of apprehension. Judge Frankel is, of course, right: usually Truth is no friend of the criminal defendant. Thus, to convert 
the defendant's only champion into yet another member of the state's legions seems an unnecessary and offensive step. It is beyond the scope of this piece to demonstrate it, but surely many within and without the bar feel that apart from the romantic dimension, an important ingredient of individualism is interwoven in the system of loyal counsel. The confidences of the humblest citizen, of the most depraved criminal are, in a criminal case, held defiantly inviolable as a demonstration that the state must do its work against us, if it will, without our help. There are assuredly other societies who think very differently about the meaning of a criminal trial in the relationship between citizen and state. And the role of counsel reflects that difference of perception. ${ }^{9}$

But, for better or worse, our view of the lawyer's duty is bound to our history and cultural traditions. Much as we might all appreciate the incremental professional honor Frankel's model promises, I fear we must live without it. For we can not tolerate an affirmative duty of betrayal laid upon defense counsel, however we might restrain his zeal by prohibition of this tactic or that.

\section{THE JUdGe}

Moving from bar to bench, it is not altogether clear to me whether Judge Frankel, while developing his contention that a judge's intervention to save Truth is frequently blundering, argues at the same time for a better informed presiding officer. He seems to debit the adversary system by the degree of imposed judicial naïveté. With some longing, our Judge seems to dream of the dossier which informs his continental counterpart. If only our system provided such a document for the trial judge, the rueful effects of adversarial zeal might be neutralized by timely and intelligent intervention from the bench.

Even assuming that wisdom accompanies information, indulging the gentle assumption that informed judicial participation in an adversary proceeding may be helpful, we might still wonder how this informative dossier is to be compiled within the American structure. Our trial judges, after all, are notand surely need not be-totally uninformed concerning the case on trial before them. Pleadings and pretrial proceedings

${ }^{9}$ I am told, for example, that in the Chinese view, defense counsel serves his client by serving the collective interest in obtaining the reformation of law breakers. 
may not convey tactical nuances of proof, but they must open a small hole in the judge's ignorance. And upon the slightest injury or show of curiosity, a judge can usually induce a trial brief and an illuminating sidebar colloquy or two. Yet, such sophistication as the trial judge readily acquires evidently does not satisfy Judge Frankel's desire for informed participation. Not so much the extent of the judge's knowledge but the source of it worries Judge Frankel. The passive judicial umpire is educated on the case by the adversaries, the very parties whose questionable commitment to the Truth necessitates judicial participation in the first place.

But if a judicial demand for enlightenment cannot produce whole and undistorted information from knowledgeable counsel, where is the judge to look for the missing ingredients of his dossier? Judge Frankel seems to regard with interest the investigation conducted in European courts by a quasijudicial figure. Here is the trustworthy file, free of partisan bias, an account of the facts adequate to equip the trial court for a Truth-saving role in the adversary process. Whatever might be the appeal to an American judge of finding upon his bench a complete set of factual findings, attested by a neutral and adept colleague, Judge Frankel should cool his enthusiasm. For again, I believe it largely idle to attempt vital organ transplants between dissimilar organisms. And the system employing the "juge d'instruction"10 or its equivalent is from root to leaf another genus. If we had an inquiring magistrate, who would be his investigators? The same police who gathered the evidence for the prosecutor's case? Or an independent and competitive body? What would be the defendant's part in the compilation of this all-important record? Adversarial? And, when all has been arranged for the production of the best and fairest dossier, have we simply created two full-fledged trials where we had one before?

Judge Frankel's footnotes suggest that one of the main attractions of the continental inquiry is the availability of the mind of the defendant himself as a source of evidence; in short, a drastic revision of our sacrosanct privilege against self-incrimination. The judge has come by an unusual route to this

10 A nonpartisan investigating magistrate, who is charged with the development of all the facts in the case. His report is arailable both to the parties and to the court. See Damaska, Evidentiay Barriers to Contiction and Tro Models of Criminal Procedure: A Comparative Study, 121 U. PA. L. REv. 506, 5556-60 (1973). 
familiar scholarly doubt concerning the fifth amendment's service in the cause of justice. I am among those who have tried to take a tradition-free view of the principle of external proof. It is immensely difficult. And it hardly seems worth the candle for the marginal enlightenment it might provide to the trial judge contemplating a more intelligent intervention in the adjudicatory process.

\section{THE "TRUTH"}

These disturbances - to the attorney-client relationship as we know it, and to the judicial role as it has developed in the American system-are relatively minor. What troubles me far more about the Frankel Formulation is his unrefined employment of the concept of Truth as though he perceived it in bold silhouette. Judge Frankel certainly requires no instruction on the plural forms and multifaceted aspects of that beguiling concept. Yet he chooses to treat it as a flat fact. He has afforded little guidance to the sort of truth he alludes to, nor to the conditions in which he regards its place as paramount. At the risk of tedious discourse (an occupational hazard after all), I feel called upon to parse some notions of Truth which slide and shift under the smooth surface of the Frankel thesis.

To begin at the simplest level, factual truth should be distinguished from legal or consequential truth. Did the victim, moments before the defendant shot him, point a six-inch blade at the defendant and say, "I'll kill you," or did he show a twoinch knife and say, "Don't come a step closer"? That is a simple issue of factual truth, and it is quite different from the question: did the defendant act in self-defense? Surely, Judge Frankel is primarily concerned with truth in the sense of a complete and accurate trial reconstruction of an objective occurrence. Or to be more precise, he would abjure any effort by counsel to limit or alter any admissible evidence which might etch, color, or erase any element of the factual picture. According to Frankel, therefore, counsel should not countenance testimony from his client that the victim "brandished a knife" if he has reason to believe that a fuller answer would disclose the two-inch blade and defensive utterance. But would Judge Frankel leave counsel free to argue all reasonable implications from a fact in evidence? May he, for example, assert the justification of self-defense suggested by the unaltered facts although from his sense of his client's temperament and experience, he 
strongly suspects that even the six-inch blade would not have unnerved the man?

Such questions raise the more fundamental problem to which I earlier adverted: how is defense counsel to know or recognize the truth? Judge Frankel, I think, proceeds from the assumption that the shining Truth is known or knowable by all diligent lawyers acting in good faith. But is it? Does the first "spontaneous" account of the accused stand thereafter as the Truth against which counsel must measure later variations in the story? Why such faith in the naive rendition? Is it any more likely to be true than, say, the versions of the witnesses against him? And what if the spontaneous descriptions of two defense witnesses vary? Is Judge Frankel suggesting not only that counsel is obliged to ferret facts, but to judge credibility as well? Should a defense be shaped according to counsel's "sense" or "suspicion" of the true state of affairs?

A somewhat more subtle dichotomy might be discovered between what I shall term the ultimate and the instrumental facts. The ultimate truth may be that the defendant had drugs in his possession, but the police witness against him may be lying about how he acquired the contraband from the defendant. Does fidelity to the truth preclude counsel's efforts to discredit the police testimony in order to obtain dismissal of the charge? I doubt whether Judge Frankel would argue the affirmative on this one. For the Constitution itself, at least as currently read by the Supreme Court, directs the release of the guilty defendant if the truth is that the evidence was unlawfully acquired. Or does the ultimate-truth-defeating quality of the exclusionary rule argue against its retention, whatever other benefits it might claim in vitalizing the Bill of Rights? To avoid that scorcher, let's take the same problem in an "ordinary" context. Suppose the lawyer is defending a man he believes committed the robbery charged but also believes that one of the witnesses against him is "improving" the case by false testimony. Attacking that witness serves the instrumental truth but may defeat the ultimate truth. Here Judge Frankel's proposition may encounter some difficulties. He cannot very well disparage counsel's good faith efforts to keep the jury's evidence as truthful as possible. Yet, if he approves defense attacks on the credibility of instrumental proof, he comes dangerously close to accepting the very adversarial tactics he elsewhere rejects. Moreover, to demonstrate falsity, counsel may have to resort 
to the "clever tricks" of cross-examination: leading questions, innuendo, magnification of conflicts in trivial detail. For, off the TV tube, a well-woven falsehood does not become unravelled by a few open-ended and respectful inquiries.

One writer, praised by Judge Frankel as "a thoughtful and humane scholar," has taken the problem one step further. Monroe Freedman argues that to achieve an ultimate truth, the acquittal of an innocent person, a lawyer may have to undermine the credibility of a witness he believes to be telling an instrumental truth. ${ }^{11}$ In Dean Freedman's example, an honest witness may give damning circumstantial evidence. ${ }^{12}$ Would Judge Frankel hold that to make the instrumentally true seem false here in order to prevent the ultimate untruth (arguments on the unreliability of circumstantial evidence are not always persuasive) constitutes a service or disservice to the interests of Truth?

Inescapably, the supremacy of Truth is easier to assert than to define. Consider the matter of justice in the result. The "search-for-the-truth" view of a criminal trial is usually employed to mean maximum correspondence between the judgment of guilt and the defendant's prior performance of the culpable conduct alleged. Yet we have developed a process which is designed over the long haul to preclude conviction of an innocent person at the social expense of acquitting some guilty defendants. I am sure Judge Frankel has no quarrel with the design of such a process. There is, then, an interest in the preservation of the process in every case though the result in a given case does not correspond to the extra-legal truth. Does Judge Frankel suggest that a lawyer who believes his client to be clearly guilty perverts Truth by holding the prosecution strictly to the burden of due process: to prove the charge beyond a reasonable doubt by admissible evidence?

When the famed Judge Sirica opened the Watergate trial by announcing that rules of evidence might be relaxed in the interests of finding the "t-r-u-t-h,"13 did his New York brother feel no qualm that important safeguards of general application might be sacrificed to a result the court deemed correct?

"Freedman, Professional Responsibility of the Criminal Defense Lauyer, $64 \mathrm{MrCH}$. L. Rev. 1469 (1966).

${ }^{12}$ Id. $1474-75$.

${ }^{13}$ See Smith, $T * R * U * T * H$ or Trial?, N.Y. Times, Nor. 4, 1974, § 1, at 37, col. 2. 
In short, while the Truth (at least as to facts) may seem simple, admitting of no "legalistic" quibbles, no shadings or interpretations, law cases are tried only on evidence of the truth. And evidence is rarely unflawed and unambiguous. Since factfinders must rely largely on human observation, recall, and veracity, on interpretation and implication, the truth is often uncertain and unclear. Indeed, the process, designed primarily to discover Truth, may at times obscure it. It is no fault of lawyers nor of the process that the evidentiary manifestations of Truth do not invariably lead to Truth.

\section{Less Drastic Remedies for More Frightful Ills}

In conclusion, I must voice my guess at the latent object of Judge Frankel's endeavor. $\mathrm{He}$ is at least as subtle and perceptive as I concerning the difficulties to which I have alluded. He knows far better than I the various manifestations of truth and the uncertainties of evidence. He cannot assume blithely that Truth shines like a compass-star by which the lawyer may navigate his case. He understands that, to the advocate in litigation, "facts" are usually a bewildering collection of shifting and contradictory fragments of professed human recollection, unverifiable hunches concerning veracity, and bits of data of uncertain import. Surely, Judge Frankel admits, as we all do, that the lawyer is gifted with no special clairvoyance to appraise the accuracy of the stories his client or others tell him. He certainly appreciates that whatever the pleas of the lawyer for truth, a defendant tries to supply a winning tale. And no reformulation of any canon can alter this basic fact in the human interaction we call the lawyer-client relationship.

What, then, has set the judge to worrying over our adversary model and its product? By respectful and altogether friendly intuition, I suspect it is the grievous case of blatant disregard for truth by counsel that sends the judge's hackles into the air. $\mathrm{He}$ is outraged by the lawyer's feigned tone of disbelief on hearing adverse testimony, his irate argument to the jury that his client was "framed" when he or his client has openly conceded culpability in another proceeding. When a lawyer during plea negotiations acknowledges his client's factual guilt, when he hears his client admit culpable facts under oath during a pretrial hearing and thereafter challenges as fabricated trial evidence of those same facts-under these circumstances, Judge Frankel concludes that the adversarial system has overstepped 
the bounds of fair truth-detection. If a lawyer puts a witness on the stand rehearsed to testify to partial truths in order to mislead the factfinder as to the whole truth, the judge's wrath boils. In these (hopefully) rare cases, perhaps we can, along with Judge Frankel, postulate a known or knowable truth; we can, along with Judge Frankel, perceive the advocate's unethical devices of distortion outside of the legitimate employment of procedural or constitutional safeguards.

To purge abuses of this nature, perhaps a more limited physic than Judge Frankel's might suffice. For example, if DR $1-102(\mathrm{~A})(4)$ and (5) $)^{14}$ are too vague and DR 7-101 and $102^{15}$ are not much better, how about a formulation such as this:

It is unprofessional conduct for a lawyer during the trial of a matter in which he represents a party to

${ }^{14}$ ABA Code of Professional Responsibility DR 1-102 Misconduct:

(A) A lawyer shall not:

....

(4) Engage in conduct involving dishonesty, fraud, deceit, or misrepresentation.

(5) Engage in conduct that is prejudicial to the administration of justice.

${ }^{15}$ Id. DR 7-101, 102.

DR 7-101 Representing a Client Zealously.

(A) A lawyer shall not intentionally:

(1) Fail to seek the lawful objectives of his client through reasonably available means permitted by law and the Disciplinary Rules, except as provided by DR 7-101 (B). A lawyer does not violate this Disciplinary Rule, however, by acceding to reasonable requests of opposing counsel which do not prejudice the rights of his client, by being punctual in fulfilling all professional commitments, by avoiding offensive tactics, or by treating with courtesy and consideration all persons involved in the legal process.

(2) Fail to carry out a contract of employment entered into with a client for professional services, but he may withdraw as permitted under DR 2-110, DR 5-102, and DR 5-105.

(3) Prejudice or damage his client during the course of the professional relationship, except as required under DR 7-102 (B).

(B) In his representation of a client, a lawyer may:

(1) Where permissible, exercise his professional judgment to waive or fail to assert a right or position of his client.

(2) Refuse to aid or participate in conduct that he believes to be unlawful, even though there is some support for an argument that the conduct is legal.

DR 7-102 Representing a Client Within the Bounds of the Law.

(A) In his representation of a client, a lawyer shall not:

(1) File a suit, assert a position, conduct a defense, delay a trial, or take other action on behalf of his client when he knows or when it is obvious that such action would serve merely to harass or maliciously injure another. 
express, convey, or indicate to the factfinder by word, gesture, or in any manner whatever his personal opinion or belief concerning any of the facts in issue or the veracity of any testimony or other evidence.

And to the wily half-truth artist, a few words might be addressed in this vein:

It is unprofessional conduct for a lawyer to counsel or countenance testimony by a witness in his favor which, although true in the part stated, omits matters which if stated might reasonably alter the meaning or significance of the testimony.

I recognize some overlap between my formulation and that proposed by Judge Frankel. But, I advance my alternative in the spirit of the adversary system as we know it. I have no purpose to reduce acknowledged faults of our adversary mechanism by altering dramatically the obligations or fealty of attorneys. Rather, I submit ethical commands-sharing Judge Frankel's faith that they are in some measure efficacious-which address specific evils within the adversary framework.

For in my opinion, it is not the adversary model itself which is to blame for the excesses which so trouble Judge Frankel, although it certainly provides the means for their employment. Victory will always be a potent lure for unscrupulous advocacy.

(2) Knowingly advance a claim or defense that is unwarranted under existing law, except that he may advance such claim or defense if it can be supported by good faith argument for an extension, modification, or reversal of existing law.

(3) Conceal or knowingly fail to disclose that which he is required by law to reveal.

(4) Knowingly use perjured testimony or false evidence.

(5) Knowingly make a false statement of law or fact.

(6) Participate in the creation or preservation of evidence when he knows or it is obvious that the evidence is false.

(7) Counsel or assist his client in conduct that the lawyer knows to be illegal or fraudulent.

(8) Knowingly engage in other illegal conduct or conduct contrary to a Disciplinary Rule.

(B) A lawyer who receives information clearly establishing that:

(I) His client has, in the course of the representation, perpetrated a fraud upon a person or tribunal shall promptly call upon his client to rectify the same, and if his client refuses or is unable to do so, he shall reveal the fraud to the affected person or tribunal.

(2) A person other than his client has perpetrated a fraud upon a tribunal shall promptly reveal the fraud to the tribunal. 
And criminal litigation, at least, has always tempted the participants to zeal. The occasional compromise of factual truth in the process, or in the outcome, is only one of the several sorts of anguish inherent in any system of penal response. And such errors must probably be borne as the price of a system of controlled contention which-like ours-gropes unsurely toward some form of justice. 